\title{
Correction to: Explaining regional inflation programmes in Indonesia: Does inflation rate converge?
}

\author{
Rudi Purwono $^{1} \cdot$ Mohammad Zeqi Yasin $^{1}$ - M. Khoerul Mubin ${ }^{1}$
}

Published online: 3 August 2021

(c) Springer Science+Business Media, LLC, part of Springer Nature 2021

\section{Correction to: Economic Change and Restructuring (2020) 53:571-590 https://doi.org/10.1007/s10644-020-09264-x}

The article "Explaining regional inflation programmes in Indonesia: Does inflation rate converge?", written by Rudi Purwono et al., was originally published online on 7 Jan 2020, without Open Access.

After publication in volume 53, issue 4, pages 571-590 the author decided to opt for Open Choice and to make the article an Open Access publication. Therefore, the copyright of the article has been changed to (C) The Author(s) 2021 and the article is forthwith distributed under the terms of the Creative Commons Attribution 4.0 International License, which permits use, sharing, adaptation, distribution and reproduction in any medium or format, as long as you give appropriate credit to the original author(s) and the source, provide a link to the Creative Commons licence, and indicate if changes were made. The images or other third-party material in this article is included in the article's Creative Commons licence, unless indicated otherwise in a credit line to the material. If material is not included in the article's Creative Commons licence and your intended use is not permitted by statutory regulation or exceeds the permitted use, you will need to obtain permission directly from the copyright holder. To view a copy of this licence, visit http://creativecommons.org/ licenses/by/4.0.

The original articles can be found online at https://doi.org/10.1007/s10644-020-09264-X.

Mohammad Zeqi Yasin

mohammad.zeqi-13@feb.unair.ac.id

Rudi Purwono

rudipurwono@feb.unair.ac.id

M. Khoerul Mubin

mkmubin@feb.unair.ac.id

1 Faculty of Economics and Business, Universitas Airlangga, Jl. Airlangga No. 4-6, Gubeng,

Surabaya 60115, Indonesia 
Publisher's Note Springer Nature remains neutral with regard to jurisdictional claims in published maps and institutional affiliations. 